\title{
Influence of Mulching on Yield and Water Use Efficiency of Perennial Forage Crops
}

\author{
Himangshu Das ${ }^{1 *}$, Champak Kumar Kundu ${ }^{2}$, Asis Mukherjee ${ }^{3}$, \\ Ratneswar Poddar ${ }^{2}$ and Pintoo Bandopadhyay ${ }^{2}$
}

${ }^{1}$ AMFU Malkangiri, Orissa University of Agriculture and Technology, KVK Malkangiri, Mundaguda, Malkangiri, Odisha- 764045, India

${ }^{2}$ Department of Agronomy, ${ }^{3}$ Department of Agricultural Meteorology and Physics, Bidhan Chandra Krishi Viswavidyalaya, Mohanpur, Nadia, West Bengal- 741252, India

*Corresponding author

\begin{tabular}{|l|}
\hline Ke y w o r d s \\
$\begin{array}{l}\text { Forage crops, } \\
\text { Mulching and water } \\
\text { use efficiency. }\end{array}$ \\
\hline Article Info \\
\hline $\begin{array}{l}\text { Accepted: } \\
\text { 07 September } 2017 \\
\text { Available Online: } \\
\text { 10 November } 2017\end{array}$ \\
\hline
\end{tabular}

\section{Introduction}

Livestock sector plays a considerable role in supplementing family incomes and generating profitable employment in the rural sector, particularly among the landless labourers, small and marginal farmers and women, in addition providing cheap nutritional food to millions of people. Livestock are the best insurance against the vagaries of nature like drought, famine and other natural calamities. Livestock production contributes $7 \%$ to the national GDP (Vision 2030, IGFRI). Despite this large livestock population, the scenario of productivity of livestock is not satisfactory. Overall improvement of livestock depends on 
different aspects, among which nutrition plays the most essential role. Forages are the main diet of animal and their production is the backbone of livestock industry. In India as well as in West Bengal forage crops are mainly cultivated in rainfed condition. As water is the most important natural resources and their use in agriculture decreasing day by day, therefore there is a need to utilize this resource with high efficiency level. In this situation soil moisture is the major constraint for crop production. Conservation agriculture has potential to support crop production through mitigating natural resource degradation (Fowler and Rockstrom, 2001; Lalet al., 2007). Appropriate soil moisture conservation practices may reduce the evaporation loss and increase the yield. Among the different soil water conservation measures, mulching has gained popularity because as it reduces the direct evaporation loss of soil water (Xieet al., 2006; Yuan et al., 2009) by restricting the transport of water vapour from soil surface to the adjoining microclimate. Thus, it increases the available soil water to the crop, which ultimately influences the yield of crop. Although a number of researchers have evaluated the positive effect of mulching in different crops, but very few work has been done on forage crops. Therefore present study was sought to evaluate the impact of mulching on yield and water use efficiency (WUE) of forage crops.

\section{Materials and Methods}

A field experiment was carried out at university research farm (latitude $22^{0} 58^{\prime} \mathrm{N}$, longitude $88^{\circ} 31^{\prime} \mathrm{E}$ and $9.75 \mathrm{~m}$ above mean sea level) during the winter and summer season of 2012-13 and 2013-14. The study site is situated in the tropical sub-humid climatic zone of eastern India. Average annual rainfall is $1608 \mathrm{~mm}$ and most of its received during June to September. January is the coldest month of this region. The total pan evaporation $\left(\mathrm{E}_{\mathrm{pan}}\right)$ and rainfall during study period are shown in Table 1. The general soil of the experimental site is classified as sandy loam (Aeric Haplaquept). The initial soil chemical properties of the surface layer (0-15 $\mathrm{cm})$ were $\mathrm{pH} 7.20$, organic carbon $5.10 \mathrm{~g} \mathrm{~kg}^{-1}$ soil, available $\mathrm{N}, \mathrm{P}_{2} \mathrm{O}_{5}$ and $\mathrm{K}_{2} \mathrm{O}$ as 190.39 , 12.50 and $145.61 \mathrm{~kg} \mathrm{ha}^{-1}$, respectively. Experiment was conducted in a split-plot design with three replications. Three perennial grasses namely Brachiaria brizantha cv. Selection $665\left(\mathrm{P}_{1}\right)$, Panicum maximum cv. Hamil $\left(\mathrm{P}_{2}\right)$ and Setaria anceps cv. Nandi $\left(\mathrm{P}_{3}\right)$ were accommodated in mainplots. Sub-plots were fitted with three different mulching: no mulching $\left(\mathrm{M}_{1}\right)$, soil dust mulching $\left(\mathrm{M}_{2}\right)$ and live mulching with legume $\left(\mathrm{M}_{3}\right)$.

This experiment was started in an experimental field of two years aged perennial grass. Sub-plot size was $5 \mathrm{~m}$ x $4 \mathrm{~m}$ with $1 \mathrm{~m}$ wide buffer strip around each plot. A spacing of $50 \times 50 \mathrm{~cm}$ between rows and plants were maintained. Before the start of experiment the field was irrigated to create favorable condition suitable for germination of seeds used for live mulch. Thereafter, live mulching was sown by opening of furrow with tyne in between two lines of perennial grass at the same time soil dust mulch was made by loosening of surface layer. Start of experiment considered when intercrop sown as live mulch and soil dust mulch was made. In winter seasons berseem @ $20 \mathrm{~kg} \mathrm{ha}^{-1}$ and in summer season cowpea @ $30 \mathrm{~kg} \mathrm{ha}^{-1}$ were sown as live mulch. Live mulching was cut after 45 days of sowing and spread over the soil surface in between lines of perennial grasses. For live mulching variety Mescavi and Bundel Lobia-2 were taken for berseem and cowpea, respectively.

Leaf area index (LAI) recorded at 15 days interval. In winter season cutting was made after 90 days of initiation of season (only 
single cut was possible due slow growth rate) and in summer season it was done at two times one after 45 days after initiation and second one after 45 days of first cutting. At harvest the forage biomass of the entire plot was recorded and converted into $\mathrm{q} \mathrm{ha}^{-1}$. Soil moisture at the beginning and end of study period was estimated at $0-150,150-300$, 300-450 and 450-600 $\mathrm{mm}$ soil depths under thermo-gravimetric method. Seasonal evapotranspiration (SET) during the entire cropping period from the crop field was calculated by using the field water balance equation described by Mukherjee and Sarkar (2009), given as:

\section{$\mathrm{SET}=\mathrm{P}+\mathrm{I}+\mathrm{C}-\mathrm{D} \pm \Delta \mathrm{SWS}$}

Where $\mathrm{P}$ is rainfall $(\mathrm{mm}), \mathrm{I}$ is irrigation $(\mathrm{mm})$, $\mathrm{C}$ is capillary contribution $(\mathrm{mm}), \mathrm{D}$ is drainage $(\mathrm{mm})$ and $\Delta S W S$ is change in soil water storage $(\mathrm{mm})$. Crop was cultivated in rainfed condition, values of capillary contribution and deep drainage were negligible and thus assumed zero. Water use efficiency (WUE) was calculated as the ratio of total green/dry matter yield to seasonal evapotranspiration (SET). The data were analyzed statistically as described by Gomez and Gomez (1984). The critical difference (CD) values were calculated at $5 \%(\mathrm{P}=0.05)$ probability level where ' $F$ ' test was significant. The statistical measurement of coefficient of determination $\left(\mathrm{R}^{2}\right)$ of the equation was determined to indicate the degree of association between two variables.

\section{Results and Discussion}

\section{Leaf Area Index (LAI)}

Irrespective of forage crops and mulches, the LAI was increased from 15 to 90 days of start of winter season (Table 2). In summer season, LAI increased from 15-45 days of start of the season and again from 60-90 days of start of the season due to one cut was made after 45 day of the start of season (Table 3). Throughout the growing period, Pooled data of two years showed significantly highest value of LAI with Setaria anceps (0.96-2.66 in winter and 1.49-3.24 in summer) during both seasons. Different leaf size and its attachment with stem varied among forage types and hence showed variation in LAI by different species (Anwar et al., 2012). Among the mulching treatments live mulching recorded the highest LAI during growing period (0.89-2.46 in winter and 1.30-3.14 in summer) followed by soil dust mulching and no mulching. Increase rate of cell division and cell size enlargement under better soil health condition due to legume mulching (Sharma et al., 2010) resulted in highest LAI with this treatment.

\section{Forage yield}

Pooled data of two years showed significant variation in green fodder yield (GFY) among different perennial grasses in both seasons (Table 4). Setaria anceps recorded significantly higher green forage yield during both seasons (91.14 q ha ${ }^{-1}$ in winter and $307.20 \mathrm{q} \mathrm{ha}^{-1}$ in summer). In terms of GFY forage crop Panicum maximum positioned $2^{\text {nd }}$ in winter season and Brachiaria brizantha in summer season. This was due to the perennial grasses have different growth habit and their response to environments is different (Langer, 1979). As like GFY, dry matter yield (DMY) was also highest with $\mathrm{P}_{3}$ followed by $\mathrm{P}_{2}$ and $P_{1}$ in winter season (Table 4). But, in summer season among the forages DMY was not significantly varied and recorded highest with $\mathrm{P}_{1}$ followed by $\mathrm{P}_{3}$ and $\mathrm{P}_{2}$ (Table 4). Differences in fresh and dry biomass of grasses are due to differences in the growth habit and morphology (Ullah et al., 2006) and variations in assimilates allocation in different organs and its partitioning in above ground parts (Bandara et al., 1999) which 
differentiate grasses in biomass production from one another. Variation in sequence of fresh and dry biomass of grasses is due to different in water content in biomass (Anwar et al., 2012). Pooled data shows that significantly highest green forage yield obtained with live mulching followed by soil dust mulching and no mulching recorded the lowest GFY (Table 4). GFY increased by 12.36 to $24.63 \%$ in winter season and 11.39 and $20.99 \%$ in summer season with live mulching treatment as compared to soil dust mulching and no mulching. Dry matter yield was also increased by 6.74 to $14.66 \%$ in winter season and 6.31 to $15.98 \%$ in summer season with live mulching treatment as compared to soil dust mulching and no mulching. Nodulation under live mulch improve soil nutrient status (Sharma et al., 2010; Caamal-Maldonado et al., 2001; Brown et al., 1993; Holderbaum et al., 1990) and on an average add 20.73 to $28.05 \mathrm{~kg}$ nitrogen ha ${ }^{1}$ during both seasons through biomass (Table 5). Cutting the intercropped legume plants and using it as mulch after 45 days helped in suppressing weed growth, and led checking evaporation losses (Narain and Singh, 1997) resulted in maximum green forage and dry matter yield obtained under live mulching. In zero mulched plots there might be more evaporation loss of moisture. Hence, the resulting water stress in the crop lead to lower values in growth attributing characters as well as green forage and dry matter yield. Soil dust mulching also conserve moisture but yield level was less than that of live mulching due to better soil health (addition of $\mathrm{N}$ ) observed with live mulching plot.

\section{Components of water balance}

In winter season, changes in soil water storage or profile contribution was more during $2^{\text {nd }}$ year as compared to $1^{\text {st }}$ year. But seasonal actual evapotranspiration (SET) was higher in $1^{\text {st }}$ year (Table 6) may be due to no rainfall during $2^{\text {nd }}$ year. In summer seasons of both years changes in soil water storage was not varied too much among the treatments and there was no regular trends (Table 7) may due to be too much rainfall before final cutting. A total of $327.60 \mathrm{~mm}$ rainfall received during summer season of $1^{\text {st }}$ year, out of this 265.88 , 267.65 and $276.62 \mathrm{~mm}$ became effective for no mulching, soil dust mulching and live mulching, respectively and that was ultimately created variation on SET. But in summer season of $2^{\text {nd }}$ year there was not too much variation for SET because total of $209.90 \mathrm{~mm}$ rainfall became effective for all treatments. In winter season, changes in soil water storage and SET values were higher for Setaria anceps $\left(\mathrm{P}_{3}\right)$ followed by Panicum maximum $\left(\mathrm{P}_{2}\right)$ and Brachiaria brizantha $\left(\mathrm{P}_{2}\right)$ during both years (Table 6). It might be due to biomass growth also having same trends and higher biomass ultimately higher uptake of moisture. There were no much more differences in SET value among different forage crops in summer season of both years (Table 7). Among the mulching management lowest changes in soil water was found with soil dust mulching, followed by no mulching and live mulching recorded the highest value in both seasons (Tables 6 and 7). Live mulching resulted in highest SET. Lowest SET was recorded under soil dust mulching. Good soil health with live mulching may increase root density and thus enhanced magnitude of water uptake which was well reflected in the value of changes in soil water storage in case of live mulching in winter season. Soil mulching disturbed the capillary tube and reduced soil moisture loss. In case of no mulching foliage growth was less but value of SET was more due higher loss of moisture from open surface through evaporation. Due to changes in soil water storage capacity among different mulching also changed in amount of effective rainfall and it was highest with $\mathrm{M}_{3}$ followed by $\mathrm{M}_{2}$ and $\mathrm{M}_{1}$ and it ultimately create variation in 
SET value during summer season of $1^{\text {st }}$ year. But in summer season of $2^{\text {nd }}$ year rainfall was not that much amount $\left(327.60 \mathrm{~mm}\right.$ in $1^{\text {st }}$ year and $209.90 \mathrm{~mm}$ in $2^{\text {nd }}$ year) to create surplus and that's why effective rainfall for all treatments were same as well as value of SET was also same (fewer difference).

Table.1 The total rainfall and pan evaporation (Epan) during growing period

\begin{tabular}{|l|c|c|c|c|c|c|c|c|}
\hline \multirow{2}{*}{$\begin{array}{l}\text { Growing } \\
\text { duration }\end{array}$} & \multicolumn{4}{|c|}{ Winter season } & \multicolumn{4}{c|}{ Summer season } \\
\cline { 2 - 9 } & Rainfall (mm) & \multicolumn{2}{c|}{$\begin{array}{c}\text { Evaporation } \\
(\mathbf{m m})\end{array}$} & \multicolumn{2}{c|}{ Rainfall (mm) } & \multicolumn{2}{c|}{$\begin{array}{c}\text { Evaporation } \\
(\mathbf{m m})\end{array}$} \\
\cline { 2 - 9 } & I year & II year & I year & II year & I year & II year & I year & II year \\
\hline 0-15 DAS & 0.00 & 0.00 & 24.20 & 28.00 & 0.00 & 17.40 & 59.50 & 52.10 \\
\hline 16-30 DAS & 0.00 & 0.00 & 18.70 & 20.20 & 0.50 & 8.80 & 78.90 & 56.40 \\
\hline 31-45 DAS & 7.30 & 0.00 & 12.80 & 16.00 & 112.50 & 0.00 & 57.70 & 70.40 \\
\hline 46-60 DAS & 1.90 & 0.00 & 14.00 & 14.00 & 7.60 & 24.90 & 64.60 & 73.20 \\
\hline 61-75 DAS & 0.00 & 0.00 & 16.60 & 13.90 & 107.20 & 5.80 & 35.50 & 88.70 \\
\hline 76-90 DAS & 0.00 & 0.00 & 24.30 & 21.00 & 99.80 & 153.00 & 41.10 & 54.10 \\
\hline
\end{tabular}

DAS- Days after start of season

Table.2 Effect of different mulching practices on leaf area index of forage crops in winter season (pooled of two years)

\begin{tabular}{|l|c|c|c|c|c|c|}
\hline Treatments & 15 DAS & 30 DAS & 45 DAS & 60 DAS & 75 DAS & 90 DAS \\
\hline \multicolumn{7}{|c|}{ Forage crops } \\
\hline Brachiaria brizantha & 0.84 & 1.04 & 1.34 & 1.75 & 1.86 & 2.23 \\
\hline Panicum maximum & 0.79 & 1.00 & 1.30 & 1.66 & 1.82 & 1.99 \\
\hline Setariaanceps & 0.96 & 1.19 & 1.75 & 2.38 & 2.47 & 2.66 \\
\hline SEm \pm & 0.040 & 0.030 & 0.028 & 0.035 & 0.029 & 0.019 \\
\hline CD at 5\% & 0.130 & 0.099 & 0.091 & 0.115 & 0.093 & 0.062 \\
\hline \multicolumn{7}{|c|}{ Mulching practices } \\
\hline No mulching & 0.83 & 1.01 & 1.37 & 1.80 & 1.87 & 2.07 \\
\hline Soil dust mulching & 0.86 & 1.05 & 1.43 & 1.91 & 2.06 & 2.33 \\
\hline Live mulching & 0.89 & 1.16 & 1.59 & 2.07 & 2.22 & 2.46 \\
\hline SEm \pm & 0.037 & 0.021 & 0.028 & 0.047 & 0.046 & 0.030 \\
\hline CD at 5\% & NS & 0.062 & 0.083 & 0.136 & 0.135 & 0.088 \\
\hline
\end{tabular}

DAS- Days after start of season 
Table.3 Effect of different mulching practices on leaf area index of forage crops in summer season (pooled of two years)

\begin{tabular}{|l|c|c|c|c|c|c|}
\hline Treatments & 15 DAS & 30 DAS & 45 DAS & 60 DAS & 75 DAS & 90 DAS \\
\hline \multicolumn{7}{|c|}{ Forage crops } \\
\hline Brachiaria brizantha & 1.14 & 1.94 & 2.98 & 1.38 & 2.16 & 3.07 \\
\hline Panicum maximum & 1.06 & 1.59 & 2.51 & 1.10 & 1.68 & 2.54 \\
\hline Setaria anceps & 1.49 & 2.30 & 3.40 & 1.71 & 2.36 & 3.24 \\
\hline SEm \pm & 0.016 & 0.027 & 0.024 & 0.047 & 0.069 & 0.025 \\
\hline CD at 5\% & 0.053 & 0.089 & 0.078 & 0.155 & 0.226 & 0.083 \\
\hline \multicolumn{7}{|c|}{ Mulching practices } \\
\hline No mulching & 1.17 & 1.81 & 2.84 & 1.33 & 1.95 & 2.84 \\
\hline Soil dust mulching & 1.22 & 1.95 & 2.98 & 1.36 & 2.02 & 2.88 \\
\hline Live mulching & 1.30 & 2.07 & 3.07 & 1.50 & 2.24 & 3.14 \\
\hline SEm \pm & 0.022 & 0.020 & 0.030 & 0.033 & 0.034 & 0.031 \\
\hline CD at 5\% & 0.065 & 0.058 & 0.089 & 0.095 & 0.099 & 0.090 \\
\hline
\end{tabular}

DAS- Days after start of season

Table.4 Influence of mulching on forage yield of different forage crops in winter and summer seasons (pooled of two years)

\begin{tabular}{|c|c|c|c|c|}
\hline \multirow[b]{2}{*}{ Treatments } & \multicolumn{2}{|c|}{ Winter season } & \multicolumn{2}{|c|}{ Summer season } \\
\hline & $\begin{array}{l}\text { Green forage } \\
\text { yield }\left(\mathbf{q} \mathbf{h a}^{-1}\right)\end{array}$ & $\begin{array}{c}\text { Dry matter } \\
\text { yield }\left(q \text { ha }^{-1}\right)\end{array}$ & $\begin{array}{l}\text { Green forage } \\
\text { yield }\left(\mathbf{q} \mathbf{h a}^{-1}\right)\end{array}$ & $\begin{array}{c}\text { Dry matter } \\
\text { yield }\left(q \text { ha }^{-1}\right)\end{array}$ \\
\hline \multicolumn{5}{|c|}{$\begin{array}{l}\text { Forage crops } \\
\end{array}$} \\
\hline Brachiaria brizantha & 78.83 & 22.33 & 288.22 & 68.73 \\
\hline Panicum maximum & 83.56 & 25.22 & 247.94 & 65.88 \\
\hline Setaria anceps & 91.14 & 26.27 & 307.20 & 66.99 \\
\hline SEm \pm & 1.10 & 0.16 & 4.08 & 0.87 \\
\hline $\mathrm{CD}$ at $5 \%$ & 3.59 & 0.53 & 13.30 & NS \\
\hline \multicolumn{5}{|c|}{ Mulching practices } \\
\hline No mulching & 75.56 & 22.92 & 255.87 & 62.02 \\
\hline Soil dust mulching & 83.81 & 24.62 & 277.92 & 67.66 \\
\hline Live mulching & 94.17 & 26.28 & 309.58 & 71.93 \\
\hline SEm \pm & 1.01 & 0.19 & 3.24 & 0.78 \\
\hline $\mathrm{CD}$ at $5 \%$ & 2.95 & 0.57 & 9.47 & 2.28 \\
\hline
\end{tabular}

Table.5 Nitrogen addition $\left(\mathrm{kg} \mathrm{ha}^{-1}\right)$ through live mulching in different treatment combinations during winter and summer season (average of two years)

\begin{tabular}{|c|c|c|}
\hline Treatments & Winter season & Summer season \\
\hline $\mathbf{P}_{\mathbf{1}} \mathbf{M}_{\mathbf{3}}$ & 21.41 & 28.00 \\
\hline $\mathbf{P}_{\mathbf{2}} \mathbf{M}_{\mathbf{3}}$ & 21.54 & 28.05 \\
\hline $\mathbf{P}_{\mathbf{3}} \mathbf{M}_{\mathbf{3}}$ & 20.73 & 27.95 \\
\hline Mean & $\mathbf{2 1 . 2 2}$ & $\mathbf{2 8 . 0 0}$ \\
\hline
\end{tabular}


Table.6 Role of mulching practices on components of water balance and water use efficiency under different forage crops during winter season

\begin{tabular}{|c|c|c|c|c|c|c|c|c|c|c|}
\hline \multirow{2}{*}{$\begin{array}{l}\text { Treat- } \\
\text { ments }\end{array}$} & \multicolumn{2}{|c|}{ SWS (mm) } & \multicolumn{2}{|c|}{ Rainfall (mm) } & \multicolumn{2}{|c|}{ SET (mm) } & \multicolumn{2}{|c|}{$\begin{array}{c}\mathrm{WUE}_{\mathrm{GF}} \\
\left(\mathrm{kg} \mathrm{ha}^{-1} \mathrm{~mm}^{-1}\right)\end{array}$} & \multicolumn{2}{|c|}{$\begin{array}{c}\mathrm{WUE}_{\mathrm{DF}} \\
\left(\mathrm{kg} \mathrm{ha}^{-1} \mathrm{~mm}^{-1}\right)\end{array}$} \\
\hline & I year & II year & I year & II year & I year & II year & I year & II year & I year & II year \\
\hline $\mathbf{P}_{1} \mathbf{M}_{1}$ & 133.2 & 134.6 & 9.2 & 0 & 142.4 & 134.6 & 52.0 & 49.7 & 15.6 & 14.8 \\
\hline $\mathbf{P}_{1} \mathbf{M}_{2}$ & 124.7 & 128.2 & 9.2 & 0 & 133.9 & 128.2 & 59.5 & 59.7 & 16.5 & 17.6 \\
\hline $\mathbf{P}_{1} \mathbf{M}_{3}$ & 134.1 & 132.7 & 9.2 & 0 & 143.3 & 132.7 & 61.7 & 66.1 & 16.5 & 17.8 \\
\hline $\mathbf{P}_{2} \mathbf{M}_{1}$ & 133.8 & 136.6 & 9.2 & 0 & 143.0 & 136.6 & 55.0 & 51.6 & 17.4 & 16.2 \\
\hline $\mathbf{P}_{2} \mathbf{M}_{2}$ & 129.1 & 130.0 & 9.2 & 0 & 138.3 & 130.0 & 63.6 & 60.8 & 19.7 & 18.2 \\
\hline $\mathbf{P}_{2} \mathbf{M}_{3}$ & 134.6 & 137.2 & 9.2 & 0 & 143.8 & 137.2 & 65.8 & 66.0 & 19.0 & 19.0 \\
\hline $\mathbf{P}_{3} \mathbf{M}_{1}$ & 134.6 & 139.0 & 9.2 & 0 & 143.8 & 139.0 & 56.6 & 59.0 & 17.9 & 16.3 \\
\hline $\mathbf{P}_{3} \mathbf{M}_{2}$ & 131.2 & 131.2 & 9.2 & 0 & 140.4 & 131.2 & 63.4 & 69.1 & 19.3 & 19.2 \\
\hline $\mathbf{P}_{3} \mathbf{M}_{3}$ & 136.5 & 142.3 & 9.2 & 0 & 145.7 & 142.3 & 70.9 & 70.6 & 20.7 & 18.8 \\
\hline
\end{tabular}

Table.7 Role of mulching practices on components of water balance and water use efficiency under different forage crops during summer season

\begin{tabular}{|c|c|c|c|c|c|c|c|c|c|c|}
\hline \multirow{2}{*}{$\begin{array}{l}\text { Treat- } \\
\text { ments }\end{array}$} & \multicolumn{2}{|c|}{ SWS (mm) } & \multicolumn{2}{|c|}{ Rainfall (mm) } & \multicolumn{2}{|c|}{ SET (mm) } & \multicolumn{2}{|c|}{$\begin{array}{c}\text { WUE } \\
\left(\mathrm{kg} \mathrm{ha}_{\mathrm{GF}}^{-1} \mathrm{~mm}^{-1}\right)\end{array}$} & \multicolumn{2}{|c|}{$\begin{array}{c}\text { WUE }_{\mathrm{DF}} \\
\left(\mathrm{kg} \mathrm{ha}^{-1} \mathrm{~mm}^{-1}\right)\end{array}$} \\
\hline & I year & II year & I year & II year & I year & II year & I year & II year & I year & II year \\
\hline $\mathbf{P}_{1} \mathbf{M}_{1}$ & 6.7 & 13.9 & 265.9 & 209.9 & 272.5 & 223.8 & 93.1 & 111.9 & 22.5 & 27.4 \\
\hline $\mathbf{P}_{1} \mathbf{M}_{2}$ & 6.6 & 13.8 & 267.7 & 209.9 & 274.2 & 223.7 & 118.2 & 120.3 & 28.3 & 29.2 \\
\hline $\mathbf{P}_{1} \mathbf{M}_{3}$ & 6.6 & 14.3 & 276.6 & 209.9 & 283.2 & 224.2 & 116.2 & 135.2 & 26.8 & 31.6 \\
\hline $\mathbf{P}_{2} \mathbf{M}_{1}$ & 6.6 & 12.4 & 265.9 & 209.9 & 272.5 & 222.3 & 88.7 & 97.0 & 23.4 & 27.6 \\
\hline $\mathbf{P}_{2} \mathbf{M}_{2}$ & 6.5 & 12.5 & 267.7 & 209.9 & 274.1 & 222.4 & 93.8 & 104.3 & 23.7 & 28.6 \\
\hline $\mathbf{P}_{2} \mathbf{M}_{3}$ & 6.7 & 13.2 & 276.6 & 209.9 & 283.3 & 223.1 & 97.6 & 112.1 & 27.3 & 28.8 \\
\hline $\mathbf{P}_{3} \mathbf{M}_{1}$ & 6.8 & 14.1 & 265.9 & 209.9 & 272.6 & 224.0 & 107.8 & 124.9 & 24.0 & 26.4 \\
\hline $\mathbf{P}_{3} \mathbf{M}_{2}$ & 6.5 & 14.2 & 267.7 & 209.9 & 274.2 & 224.1 & 108.7 & 128.3 & 25.6 & 28.7 \\
\hline $\mathbf{P}_{3} \mathbf{M}_{3}$ & 6.8 & 14.2 & 276.6 & 209.9 & 283.4 & 224.1 & 128.9 & 133.2 & 26.3 & 30.6 \\
\hline
\end{tabular}

Fig.1 Relationship between green forage yield and seasonal evapotranspiration (SET) under different forage crops and mulching practices in winter season

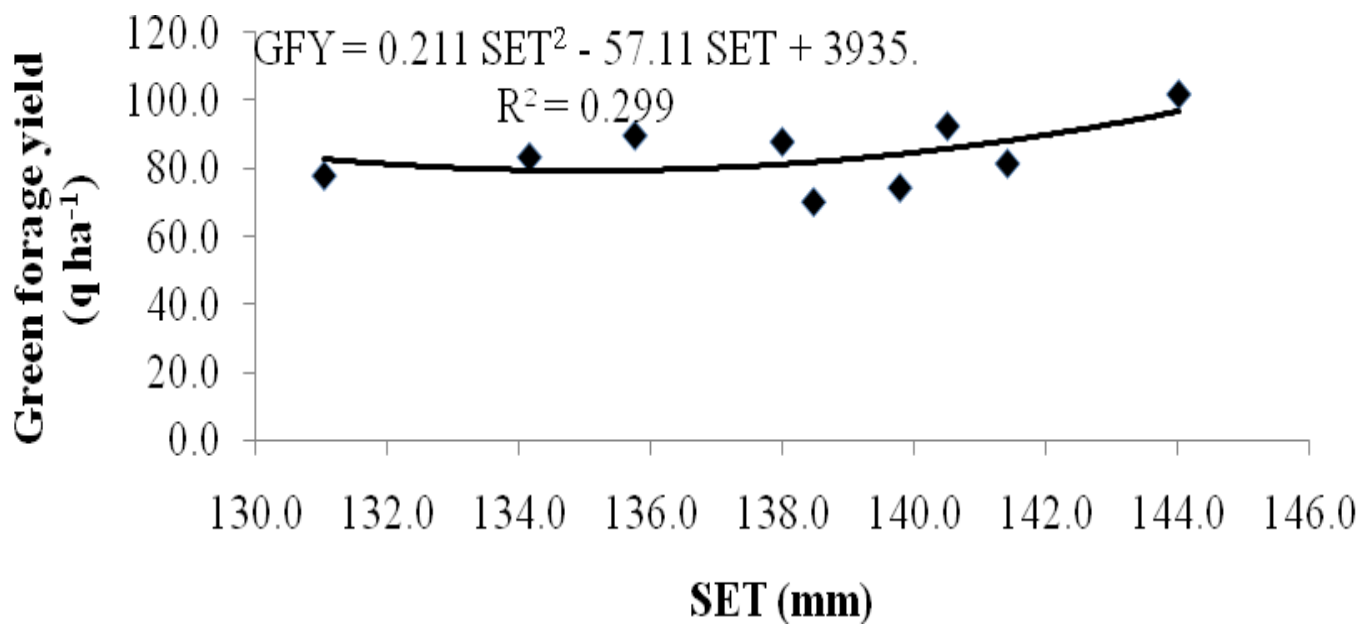


Fig.2 Relationship between green forage yield and seasonal evapotranspiration (SET) under different forage crops and mulching practices in summer season

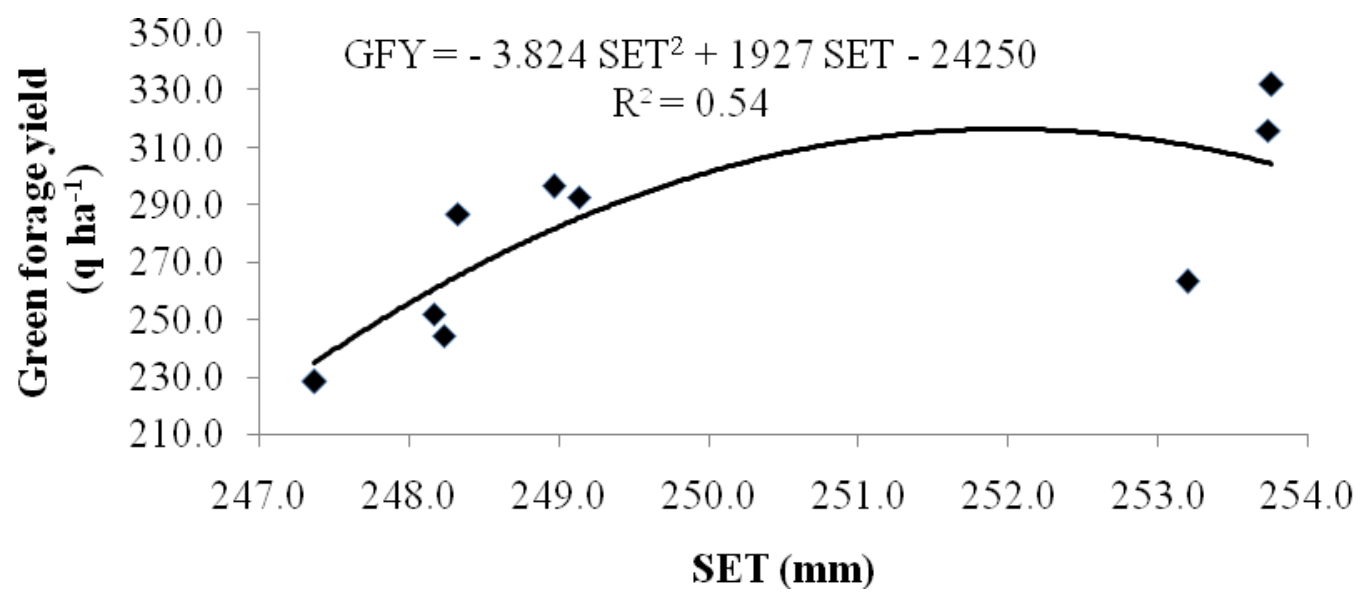

\section{Green forage yield-SET relationship}

Curvilinear relationship in between green forage yield and SET was obtained during both seasons using all 9 data points obtained during the study period (averaged of two years). Green forage yield increased continuously with increase in SET in increasing rate in winter season. In summer season it showed that GFY increased continuously with increase in SET value up to certain level and thereafter decreases gradually. The regression equation shows that about $30 \%$ and $54 \%$ variation in GFY could be explained by SET value in winter and summer season, respectively (Figs. 1 and 2). Clubbing of different forage crops with mulching may be the reasons for lower $R^{2}$ value. Coefficient a and $c$ have negative value in summer, it means highest GFY is not matched with the higher SET value.

\section{Water use efficiency (WUE)}

WUE was assessed in terms of both green $\left(\mathrm{WUE}_{\mathrm{GF}}\right)$ and dry biomass ( $\left.\mathrm{WUE}_{\mathrm{DF}}\right)$. The mean value of $\mathrm{WUE}_{\mathrm{GF}}$ in winter season was maximum with Setaria anceps $\left(\mathrm{P}_{3}\right)$ followed by Panicum maximum $\left(\mathrm{P}_{2}\right)$ and Brachiaria brizantha $\left(\mathrm{P}_{1}\right)$ during both years (Table 6$)$. This trend was also followed for $\mathrm{WUE}_{\mathrm{DF}}$. The rate of increment of SET was lower than the rate of increment in yield and this led to higher WUE under $\mathrm{P}_{3}$ as compared to others. In summer season, the mean value of $\mathrm{WUE}_{\mathrm{GF}}$ was maximum with Setaria anceps followed by Brachiaria brizantha and Panicum maximum during both years, but the sequence was differed in case of WUE $E_{D F}$ and it was $\mathrm{P}_{1}>\mathrm{P}_{3}>\mathrm{P}_{2}$ (Table 7). This might due to be relative increase in forage yield was more as compared to relative increase in SET value irrespective of grasses. WUE $_{\mathrm{DF}}$ did not matched with $\mathrm{WUE}_{\mathrm{GF}}$ in summer season may be due to dry biomass recorded higher with $\mathrm{P}_{1}$ followed by $\mathrm{P}_{3}$ and $\mathrm{P}_{2}$ due to variation in dry matter content among different forage types (Anwar et al., 2012). The magnitude of WUE (both $\mathrm{WUE}_{\mathrm{GF}}$ and $\mathrm{WUE}_{\mathrm{DF}}$ ) was lowest under no mulching $\left(\mathrm{M}_{1}\right)$ condition followed by soil dust mulching $\left(\mathrm{M}_{2}\right)$ and it was highest with live mulching with legume $\left(\mathrm{M}_{2}\right)$ during both seasons and years (Table 6 and 7). On an average there were little differences in SET between $\mathrm{M}_{1}$ and $\mathrm{M}_{3}$. But, 14.66 and $24.63 \%$ green and dry matter yield increased by $\mathrm{M}_{3}$ as compared to $\mathrm{M}_{1}$ in winter season and 15.98 and $21.00 \%$ in summer season responsible for increasing WUE with $\mathrm{M}_{3}$. On other hand $\mathrm{M}_{2}$ that recorded lowest SET value and highest yield as compared to $\mathrm{M}_{1}$ and positioned second in terms of WUE. 
It can be concluded that among the different forage crops Setaria anceps gave highest forage yield with maximum water use efficiency. The results also indicate the adaptation of live mulching has an important role on increasing forage yield along with highest water use efficiency. Considering both yield and water use efficiency farmers of Eastern India can be advised to cultivate forage crop Setaria anceps with live mulching practice.

\section{References}

Anwar, M., Akmal, M., Shah, A., Asim, M. and Gohar, R. 2012. Growth and yield comparison of perennial grasses as rainfed fodder production. Pak. J. Bot., 44: 547552.

Bandara, G.D., Whitehead, D., Mead, D.J. and Moot, D.J. 1999. Effects of pruning and understorey vegetation on crown development, biomass increment and above-ground carbon partitioning in Pinus radiata $\mathrm{D}$. Don trees growing at a dryland agroforestry site. Forest Eco. Mang.172: 241-254

Brown, R.W., Varvel, G.E. and Shapiro, C.A. 1993. Residual effects of interseeded hairy vetch on soil nitrate-nitrogen levels. Soil Sc. Soc. America J.57: 121-124.

Caamal-Maldonado, J.A., Jimenez-Osornio, J.J., Torres-Barragan, A. and Anaya, A.L. 2001. The use of allelopathic legume cover and mulch species for weed control in cropping systems. Agron. J.93: 27-36.

Fowler, R. and Rockstrom, J. 2001. Conservation tillage for sustainable agriculture: an agrarian revolution gathers momentum in Africa. Soil Til. Res., 61: 93-108.

Gomez, K. and Gomez, A.A. 1984. "Statistical Procedures for Agricultural Research". $2^{\text {nd }}$ Eds. (A wiley Interscience publication, New York) pp. 680.

Holderbaum, J.F., Decker, A.M., Meisinger, J.J.,
Mulford, F.R and Vough, L.R. 1990. Fallseeded legume cover crops for no-tillage corn in the humid east. Agron. J.82: 117124.

Lal, R., Reicosky, D.C. and Hanson, J.D. 2007. Evolution of the plow over 10,000 years and the rationale for no-till farming. Soil Til. Res., 93: 1-12.

Langer, R.H.M. 1979. How grasses grow, $2^{\text {nd }}$ Ed. Edward Arnold (Publishers) Ltd. London.

Mukherjee, A. and Sarkar, S. 2009. Relationship between actual evapotranspiration estimated by water balance method and soil moisture depletion method in tomato. $J$. Agromet., 11: 111-114.

Narain, P. and Singh, R.K. 1997. Erosion control and productivity through sunnhemp mulching and green manuring. Annual Report. Central Soil and water Conservation Research and Training Institute, Dehradun, pp 40-41.

Sharma, A.R., Singh, R., Dhyani, S.K. and Dube, R.K. 2010. Moisture conservation and nitrogen recycling through legume mulching in rainfed maize (Zea mays)wheat (Triticum aestivum) cropping system. Nutr. Cycl. Agroecosyst., 87: 187-197.

Ullah, M.A., Razzaq, A. and Saleem, R. 2006. Performance of various forage grasses under spring and monsoon season at pothowar plateau (Pakistan). Int. J. Agric. Bio., 3: 398-401.

Vision 2030, IGFRI. 2011. Indian Grassland and Fodder Research Institute, Jhansi (UP). pp 48.

Xie, Z., Wang, Y., Jiang, W. and Wei, X. 2006. Evaporation and evapo- transpiration in a watermelon field mulched with gravel of different sizes in northwest China. Agric. Water Mang, 81: 173-184.

Yuan, C., Lei, T., Mao, L., Liu, H. and Wu, Y. 2009. Soil surface evaporation processes under mulches of different sized gravel. Catena.78: 117-121.

\section{How to cite this article:}

Himangshu Das, Champak Kumar Kundu, Asis Mukherjee, Ratneswar Poddar and Pintoo Bandopadhyay. 2017. Influence of Mulching on Yield and Water Use Efficiency of Perennial Forage Crops. Int.J.Curr.Microbiol.App.Sci. 6(11): 792-800. doi: https://doi.org/10.20546/ijcmas.2017.611.093 